\title{
BIOREDUCTION OF SUBSTITUTED $\alpha$-TETRALONES PROMOTED BY Daucus carota ROOT
}

Helena M. C. Ferraz ${ }^{\dagger}$, Graziela G. Bianco*, Fernanda I. Bombonato e Leandro H. Andrade

Instituto de Química, Universidade de São Paulo, CP 26077, 05513-970 São Paulo - SP, Brazil

André L. M. Porto

Instituto de Química de São Carlos, Universidade de São Paulo, CP 780, 13560-970 São Carlos - SP, Brazil

Recebido em 15/1/08; aceito em 27/2/08; publicado na web em 2/4/09

\begin{abstract}
The bioreduction of a series of substituted $\alpha$-tetralones, carried out using Daucus carota root (carrot), afforded the corresponding homochiral $\alpha$-tetralols in variable conversions ( 9 to $90 \%$ ) and excellent enantiomeric excesses. Two of the assayed $\alpha$-tetralones were resistant to the bioreduction conditions. The absolute configurations of four $\alpha$-tetralols were assigned as being $(S)$, by comparison to the $(S)$-enantiomers obtained by kinetic resolution promoted by CALB-catalysed acetylation. Additionally, the new 5-methoxy-6-methyl-1-tetralone was synthesized in seven steps from 3-methylsalicylic acid.
\end{abstract}

Keywords: bioreduction; Daucus carota; $\boldsymbol{\alpha}$-tetralols.

\section{INTRODUCTION}

$\alpha$-Tetralols are versatile intermediates in organic synthesis, being employed as building blocks and as catalysts ligands. ${ }^{1-4}$ Therefore, many efforts have been dedicated to search for reactions that can furnish homochiral $\alpha$-tetralols. There are several reports dealing with the asymmetric hydrogenation of the $\alpha$-tetralone itself, ${ }^{5-11}$ as well as with its bioreduction, using either isolated enzymes or microorganisms. ${ }^{12-16}$ It is of note that substituted homochiral $\beta$-tetralols have been obtained by reacting a large variety of enzymes and microorganisms with the corresponding $\beta$ tetralones. ${ }^{11,17-21}$ To our knowledge, however, there are no previous works dealing with the analogous substituted $\alpha$-tetralones.

In a recent paper, we reported the enzymatic kinetic resolution of a series of $\alpha$-tetralols, using the lipase B from Candida antarctica (CALB). ${ }^{22}$ The $(S)$-1-tetralols and their respective $(R)$-acetates were obtained in excellent enantiomeric excesses. The absolute configurations of the products were assigned by comparison of the optical rotation values to those of literature. These results are summarized in Scheme 1.

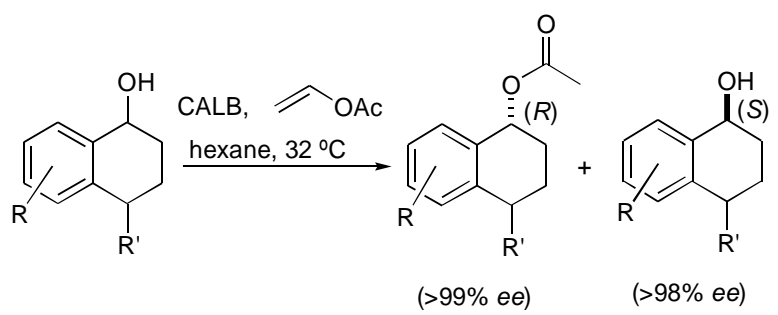

Scheme 1

The Daucus carota root is frequently used to promote the bioreduction of a number of ketones, constituting an efficient way for the preparation of enantiomerically pure secondary alcohols. ${ }^{12,23-30}$ To our knowledge, there is just one paper concerning the Daucus carota promoted bioreduction of two $\alpha$-tetralones, namely the $\alpha$-tetralone

$\dagger$ in memorian, 1948-2007.

\$ This article is dedicated to Prof. Helena M. C. Ferraz

* e-mail: grazielabianco@gmail.com itself and the 6-methoxy-1-tetralone. ${ }^{12}$

Therefore, we decided to investigate the behaviour of a series of substituted $\alpha$-tetralones towards the bioreduction with Daucus carota, aiming higher yields (theoretically 100\%) than those earlier obtained using CALB in the kinetic resolution (theoretically 50\%). ${ }^{22}$ Moreover, the $\alpha$-tetralol derivatives could be useful model substrates in our studies concerning the synthesis of some natural products, such as the sesquiterpenes mutisianthol (I) ${ }^{31,32}$ and jungianol (II), ${ }^{33-35}$ and the lignane flossonol (III) $)^{36}$ (Figure 1).<smiles>CC(C)=C[C@@H]1CC(C)c2cc(O)c(C)cc21</smiles>

(I)

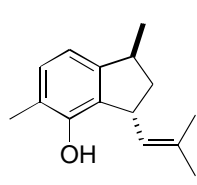

(II)<smiles>COc1cc2c(cc1C)C(=O)C(C)CC2O</smiles>

(III)
Figure 1. Mutisianthol (I), jungianol (II) and flossonol (III)

\section{RESULTS AND DISCUSSION}

A series of nine substituted $\alpha$-tetralones, besides the $\alpha$-tetralone itself (Figure 2) were employed as substrates for the bioreduction studies. The tetralones 1a-7a are commercially available, while the others (8a-10a) were synthesized as described in the next sections.

The $\alpha$-tetralones 8a and 10a were prepared according to known procedures from 2-methyl-anisole, as depicted in Scheme 2. ${ }^{32,37}$<smiles>O=C1CCCc2ccccc21</smiles>

$1 \mathrm{a}$<smiles>[R6]c1c(Br)cc2c(c1Br)CCCC2=O</smiles>

2a-5a, 8a-9a

2a. $\mathrm{R}_{2}=\mathrm{R}_{3}=\mathrm{H} ; \mathrm{R}_{1}=\mathrm{OM}$ 3a. $R_{1}=R_{3}=H ; R_{2}=O M e$ 4a. $\mathrm{R}_{1}=\mathrm{R}_{2}=\mathrm{H} ; \mathrm{R}_{3}=\mathrm{OMe}$ 5a. $R_{2}=H ; R_{1}=R_{3}=M e$ 8a. $R_{1}=H ; R_{2}=M e ; R_{3}=O M e$ 9a. $R_{3}=H ; R_{1}=O M e ; R_{2}=M e$

Figure 2. Tetralones 1a-10a<smiles>[R5]C1CC([R8])c2ccccc2C1=O</smiles>

6a-7a

6a. $\mathrm{R}_{5}=\mathrm{H} ; \mathrm{R}_{4}=\mathrm{Me}$ 7a. $\mathrm{R}_{5}=\mathrm{Me} ; \mathrm{R}_{4}=\mathrm{H}$<smiles>COc1cc2c(cc1C)C(=O)CCC2C</smiles>

$10 a$ 
<smiles>COc1ccc(CCCOC(=O)C(C)(C)c2ccc(OC)c(C)c2)cc1C</smiles>

$8 \mathbf{a}$<smiles>COc1cc2c(cc1C)CCC(C)C2C(C)C</smiles>

10a

Scheme 2. Reagents and conditions: a) succinic anhydride, $\mathrm{C}_{6} \mathrm{H}_{5} \mathrm{NO}_{2}, \mathrm{AlCl}_{3}$, $0-5^{\circ} \mathrm{C}, 24 \mathrm{~h}$; b) $\mathrm{Zn}(\mathrm{Hg}), \mathrm{H}_{2} \mathrm{O}, \mathrm{HCl}$, toluene, $r t, 48 \mathrm{~h}$; c) trifluoracetic acid, trifluoracetic anhydride, rt, $10 \mathrm{~min}$; d) $\mathrm{i}: \mathrm{MeMgI}, \mathrm{Et}_{2} \mathrm{O}$, reflux, $1 \mathrm{~h}$; ii: $10 \%$ $\mathrm{HCl}, \mathrm{rt}, 3 \mathrm{~h}, \mathrm{e}) 6 \mathrm{~atm} \mathrm{H}_{2(\mathrm{~g})}, \mathrm{Pd} / \mathrm{C}, \mathrm{rt}, 16 \mathrm{~h}$; f) $\mathrm{CrO}_{3}, \mathrm{H}_{2} \mathrm{O} / \mathrm{AcOH}, \mathrm{rt}, 20 \mathrm{~min}$

The $\alpha$-tetralone 9a was synthesized in seven steps from 3methylsalicylic acid (11), as summarized in Scheme 3. Although the 2-methoxy-3-methyl benzaldehyde (12) is commercially available, this compound was prepared in 3 steps from the acid 11, through known reactions. ${ }^{38}$ Addition of the alkyllithium $\mathbf{1 3}$ to the aldehyde $\mathbf{1 2}$ afforded the intermediate $\mathbf{1 4}$, which was then submitted to hydrogenolysis under acidic conditions. These conditions promoted the concomitant deprotection of the silylether, furnishing the primary alcohol $\mathbf{1 5}$ in $85 \%$ yield from 12. Oxidation of $\mathbf{1 5}$ with Jones reagent, followed by intramolecular cyclization, led to the desired product 9a in $81 \%$ yield for the two steps.<smiles>COc1c(C)cccc1C(=O)[CH+]C[Al]CCCO[SbH2]</smiles><smiles>COc1c(C)cccc1CCCO</smiles><smiles>COc1c(C)cccc1CCCC(=O)O</smiles><smiles>COc1c(C)ccc2c1CCCC2=O</smiles>

Scheme 3. Reagents and conditions: a) $\mathrm{LiAlH}_{4}, \mathrm{THF}, \mathrm{N}_{2(g)}$,rt, $16 \mathrm{~h}$; b) MeI, $\mathrm{K}_{2} \mathrm{CO}_{3}$, acetone, $\left.\left.\left.85^{\circ} \mathrm{C}, 16 \mathrm{~h} ; \mathrm{c}\right) \mathrm{PCC}, \mathrm{CH}_{2} \mathrm{Cl}_{2}, \mathrm{rt}, 3 \mathrm{~h} ; \mathrm{d}\right) \mathrm{THF}, \mathrm{O}^{\circ} \mathrm{C}, 2 \mathrm{~h} ; \mathrm{e}\right) 4$ atm $\mathrm{H}_{2(\mathrm{~g}),} \mathrm{Pd} / \mathrm{C}, \mathrm{HClO}_{4}, \mathrm{rt}, \mathrm{l} 6 \mathrm{~h}$; f) $\mathrm{CrO}_{3} / \mathrm{H}_{2} \mathrm{SO}_{4}$, acetone, $\mathrm{O}^{\circ} \mathrm{C}, 2 \mathrm{~h} ; \mathrm{g}$ ) polyphosphoric acid, $65^{\circ} \mathrm{C}, 1 \mathrm{~h}$

The tetralones were initially submitted to reduction with sodium borohydride, to obtain the racemic patterns of the tetralols. Several of them $(\mathbf{1 b}, \mathbf{4 b}-\mathbf{8 b})$ could not be analytically resolved by chiral gas chromatography, and therefore were acetylated using classical conditions. The results are shown in Scheme 4.

The $\alpha$-tetralones 1a-10a were then submitted to the reaction with carrot, in a phosphate buffered aqueous medium, employing acetonitrile and ethanol for solubilization of the substrates. The

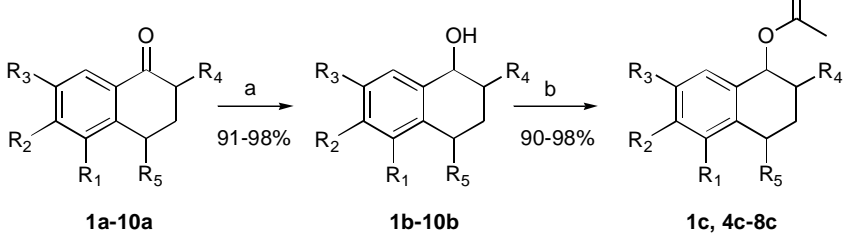

Scheme 4. Reagents and conditions: a) 2 eq. $\mathrm{NaBH}_{4}, \mathrm{MeOH}, \mathrm{O}^{\circ} \mathrm{C}$-ta, $1 \mathrm{~h}$; b) 3 eq. $\mathrm{Ac}_{2} \mathrm{O}, \mathrm{Et} \mathrm{N}_{3} \mathrm{~N}, \mathrm{DMAP}, \mathrm{ta}, \mathrm{h}$

erlenmeyers containing the reactional mixture were stirred at $32{ }^{\circ} \mathrm{C}$ and $180 \mathrm{rpm}$ during 4 days. In the first set of experiments (conditions A, Table 1), for $20 \mathrm{mg}$ of the tetralones were used $10 \mathrm{~g}$ of carrot. In the second set (conditions B, Table 1) the amount of carrot was doubled.

Table 1. Bioreduction of the $\alpha$-tetralones 1a-10a mediated by Daucus carota root in 4 days

phosphate buffered

\begin{tabular}{|c|c|c|c|c|}
\hline \multirow[b]{2}{*}{ Substrate } & \multicolumn{2}{|c|}{ Conditions $A^{a}$} & \multicolumn{2}{|c|}{ Conditions $B^{b}$} \\
\hline & $\begin{array}{l}\text { Conver- } \\
\text { sion }^{\mathrm{c}, \mathrm{d}} \\
(\%)\end{array}$ & $\begin{array}{c}e e^{\mathrm{d}} \text { of } \mathbf{1 b}-\mathbf{1 0 b} \\
(\%) \\
(\text { conf. })\end{array}$ & $\begin{array}{l}\text { Conver- } \\
\text { sion }^{\mathrm{c}, \mathrm{d}} \\
(\%)\end{array}$ & $\begin{array}{c}e e^{\mathrm{d}} \text { of } \mathbf{1 b}-\mathbf{1 0 b} \\
(\%) \\
(\text { conf. })\end{array}$ \\
\hline $1 \mathbf{a}$ & 57 & $95(S)$ & 88 & $95(S)$ \\
\hline $2 \mathbf{a}$ & 80 & $>99(S)$ & 13 & 1 \\
\hline $3 \mathbf{a}$ & 11 & 60 (nd) & 29 & $30(\mathrm{nd})$ \\
\hline $4 a$ & 82 & $>99(S)$ & 90 & $98(S)$ \\
\hline $5 \mathbf{a}$ & 20 & $>99(S)$ & 53 & $97(S)$ \\
\hline $6 \mathbf{a}$ & 0 & - & 0 & - \\
\hline $7 \mathbf{a}$ & 37 & cis: 64; trans: 99 & 79 & cis: $90 ;$ trans: 97 \\
\hline $8 \mathbf{a}$ & 9 & $>99$ (nd) & 34 & $>99$ (nd) \\
\hline $9 \mathbf{a}$ & 75 & $>99$ (nd) & 70 & $85(\mathrm{nd})$ \\
\hline $10 \mathbf{a}$ & 0 & - & 0 & - \\
\hline
\end{tabular}

a $20 \mathrm{mg}$ of 1a-10a in $40 \mathrm{~mL}$ of phosphate buffer and $10 \mathrm{~g}$ of Daucus carota root. ${ }^{\mathrm{b}} 20 \mathrm{mg}$ of $\mathbf{1 a - 1 0 a}$ in $80 \mathrm{~mL}$ of phosphate buffer and 20 $\mathrm{g}$ of Daucus carota root. ${ }^{\mathrm{c}}$ Conversion of $\mathbf{1 a - 1 0 a}$ to the alcohols $\mathbf{1 b}$ $\mathbf{1 0 b}$ after acetylation reaction of $\mathbf{1 b}, \mathbf{4 b - 8 b} .{ }^{\mathrm{d}}$ Determined by chiral GC. nd: not determined; conf: configuration.

The conversions of the $\alpha$-tetralones to the $\alpha$-tetralols in the conditions A were variable, ranging from 9 to $82 \%$, while the enantiomeric excesses were very good for the majority of the obtained $\alpha$-tetralols. Doubling the amount of carrot (conditions B) increased the conversion of six tetralones, namely 1a, 3a, 4a, 5a, $7 \mathbf{a}$ and 8a, but the enantiomeric excess was better just for the reduction of 7a. The tetralone $\mathbf{2 a}$ gave a high enatiomeric excess and conversion in the conditions A. However, it was surprising that in the conditions B these good results could not be reproduced. The tetralones $\mathbf{6 a}$ and $\mathbf{1 0 a}$ were resistant to both the reduction conditions.

A possible explanation for the lack of reactivity of the tetralone 6a would be the $\alpha$-carbonylic position of the methyl group, which certainly causes a steric hindrance. It is of note that the difficulty of the analogous tetralol $\mathbf{6 b}$ in reacting with isolated enzymes ${ }^{22,39}$ and microorganisms $\mathrm{s}^{40}$ was already observed. The tetralone 10a 
showed to be resistant also to chemical reduction, requiring 5 equivalents of sodium borohydride for the preparation of $( \pm)-\mathbf{1 0 b} .{ }^{32}$

The chromatograms of the products obtained in the bioreduction of the $\alpha$-tetralones 1a and $\mathbf{4 a}$ are presented in Figures 3 and 4, respectively.

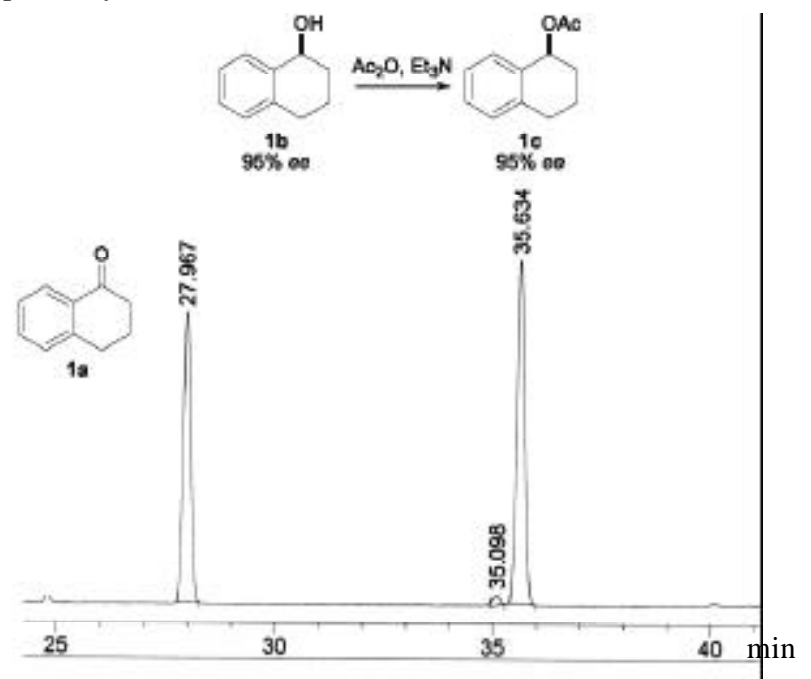

Figure 3. Chromatogram obtained after bioreduction of tetralone $\mathbf{1 a}$ in the conditions A
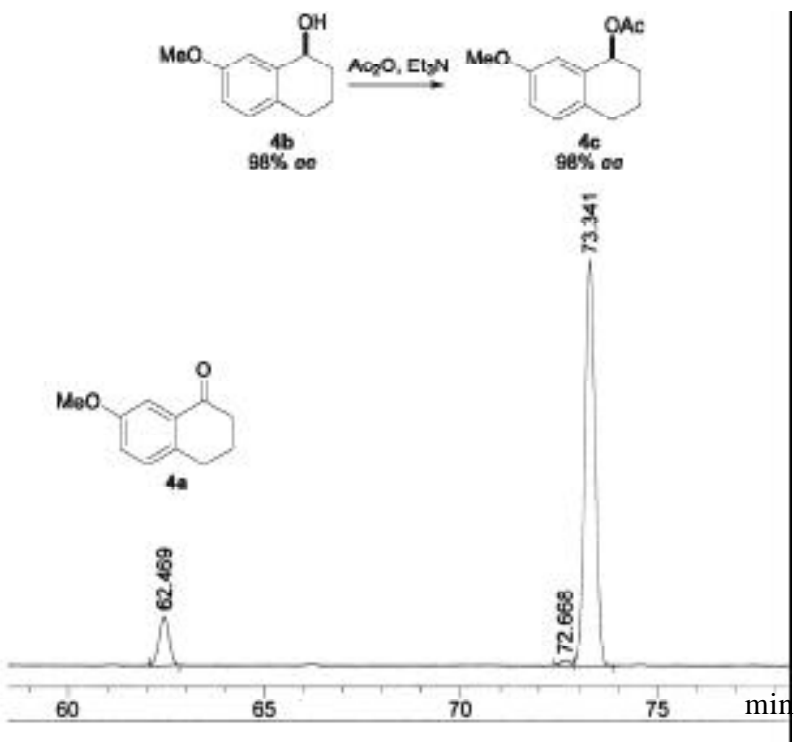

Figure 4. Chromatogram obtained after bioreduction of tetralone $\mathbf{4 a}$ in the conditions $B$

We have assigned the $(S)$-configuration to the tetralols $\mathbf{1 b}, \mathbf{2} \mathbf{b}$, $\mathbf{4 b}$ and $\mathbf{5 b}$, by comparison of the retention time in the GC analysis with those obtained previously for these tetralols. ${ }^{22}$ The $(S)$ configuration agrees to Prelog's rule,$^{41}$ which predict that hydrogen transfer to the prochiral ketone occurs to the face where the large group is in the right side (Figure 5a), in this case the $R e$-face (Figu-

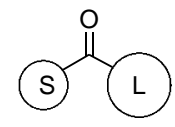

S: Small group L: Large group

(a)

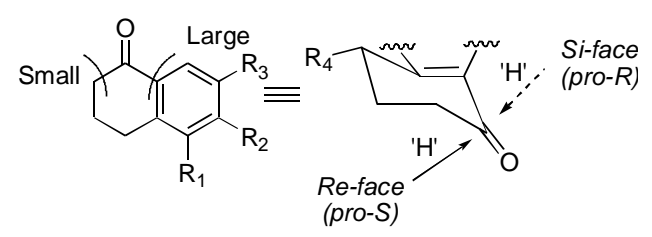

(b)

Figure 5. (a) Ketone more reactive (b) Prelog's rule applied to the $\alpha$-tetralones re 5b). Additionally, Yadav et al. ${ }^{12}$ attributed the $(S)$-configuration to the $\alpha$-tetralol (1b) and to the 6-methoxy-1-tetralol (3b) obtained by bioreduction mediated by carrot of the corresponding $\alpha$ tetralones.

Finally, the bioreduction of the tetralone $( \pm)-7 \mathbf{a}$ led to either the enantiomer of the cis isomer $(90 \%$ ee) and of the trans isomer ( $97 \% e e$ ). This result showed that the keto-reductase from carrot (probably pro-S enantioselective) was not sensitive to substituents at the 4-position, since a mixture of 1:1 (cis:trans) was obtained (Figure 6). It is noteworthy that Bégué et al. observed a similar behaviour when $( \pm)-\mathbf{7 a}$ was submitted to bioreduction mediated by Rhodotorula rubra. ${ }^{42}$

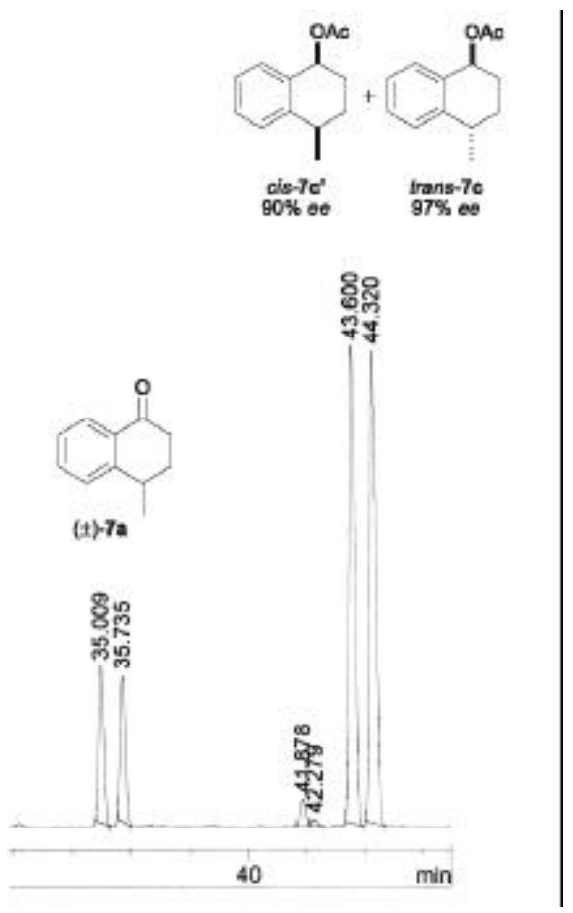

Figure 6. Chromatogram obtained after bioreduction of tetralone ( \pm )-7a in the conditions $B$ - signals at 41.88 and $43.60 \mathrm{~min}$ : cis-enantiomer $7 c^{\prime}$; signals at 42.28 and 44.32 min: trans-enantiomer $7 c$

\section{CONCLUSION}

The Daucus carota-promoted bioreduction of eight substituted $\alpha$-tetralones afforded the corresponding homochiral alcohols in conversions ranging from 9 to $90 \%$ and in very good enantiomeric excesses. Four of the $\alpha$-tetralols thus obtained have the absolute configuration assigned as $(S)$. This biotransformation may be an useful tool for the asymmetric synthesis of natural products with biological properties such as flossonol. ${ }^{36}$

\section{EXPERIMENTAL}

\section{General}

All solvents and chemicals used were previously purified according to the usual methods. Column chromatography was performed using silica gel 200-400 mesh. ${ }^{1} \mathrm{H}$ and ${ }^{13} \mathrm{C}$ NMR spectra were measured in $\mathrm{CDCl}_{3}$ with TMS as the internal standards and recorded on Bruker and Varian spectrometers. IR spectra were measured on a Perkin-Elmer 1750-FT. Gas chromatography analyses were performed in a HP-6890 series II. Conversions and enantiomeric excesses were determined using a HP-6890 series II 
gas chromatograph equipped with a chiral capillary column AG1002000 (packed with $\beta$-cyclodextrin $(30 \mathrm{~m} \times 0.32 \mathrm{~mm} \times 0.25 \mu \mathrm{m})-$ Agilent-HP). The carrier gas was hydrogen. GC-MS analyses were performed using Finnigan-MAT INCOS 50B and GC Varian 2400. Elemental analyses were performed using Perkin-Elmer 2400 apparatus. High-resolution mass spectra were performed on a Bruker Daltonics Microtof Eletrospray instrument. The carrot was bought in a local market. The racemic tetralols $\mathbf{1 b}, \mathbf{2 b}, \mathbf{4 b}-\mathbf{8 b}$ and acetates 1c, $4 \mathbf{c}-\mathbf{8 c}$ were prepared according to known procedures. ${ }^{22}$ The spectroscopic data of these compounds were identical to those earlier reported. ${ }^{22}$

\section{Preparation of the tetralone 9a}

4-(triisopropylsililoxy)-1-(2-methoxy-3-methylphenyl)butane-1-ol (14)

To a two-necked flask, under nitrogen, was added metallic lithium $(0.88 \mathrm{~g}, 0.13 \mathrm{~mol})$ in small pieces that was washed with dry hexanes. After a few minutes under nitrogen, (3bromopropoxy)triisopropylsilane $(8.8 \mathrm{~g}, 30 \mathrm{mmol})$ was added in dry THF $(100 \mathrm{~mL})$. This solution was irradiated by ultrasound for $2 \mathrm{~h}$. The grey solution of $\mathbf{1 3}$ was transferred by cannula to another two-necked flask equipped with a magnetic stirrer, ice bath and under nitrogen containing a solution of aldehyde $12(3.0 \mathrm{~g}, 20 \mathrm{mmol})$ in dry $\mathrm{Et}_{2} \mathrm{O}(100 \mathrm{~mL})$. This mixture was stirred for $2 \mathrm{~h}$ at $0{ }^{\circ} \mathrm{C}$. The reaction was quenched with water and then extracted with EtOAc. The combined organic layers were washed with water, brine and then dried with anhydrous $\mathrm{MgSO}_{4}$. The solvent was removed under reduced pressure and the resulting residue was purified by flash chromatography [silica gel 200-400 mesh, eluent with a mixture of 7:3 hexanes: EtOAc] to afford $14(6.6 \mathrm{~g}, 18 \mathrm{mmol}, 90 \%)$ as a colorless oil. ${ }^{1} \mathrm{H}$ NMR $(300 \mathrm{MHz}) \delta$ : $1.04-1.15(\mathrm{~m}, 21 \mathrm{H}), 1.60-$ $1.97(\mathrm{~m}, 4 \mathrm{H}), 2.29(\mathrm{~s}, 3 \mathrm{H}), 3.75-3.79(\mathrm{~m}, 5 \mathrm{H}), 5.02(\mathrm{dd}, J 7.7$ and $4.8 \mathrm{~Hz}, 1 \mathrm{H}), 7.00-7.05(\mathrm{~m}, 1 \mathrm{H}), 7.06-7.10(\mathrm{~m}, 1 \mathrm{H}), 7.27-7.30(\mathrm{~m}$, $1 \mathrm{H}) ;{ }^{13} \mathrm{C}$ NMR (75 MHz) $\delta: 12.0,16.1,18.0,29.8,35.7,60.8,63.6$, 69.0, 124.2, 124.6, 130.2, 130.7, 137.7, 155.7; IR (film) $\mathrm{v}_{\text {máx }} / \mathrm{cm}^{-1}$ : 3418; LRMS (EI) $\mathrm{m} / \mathrm{z}(\%): 175\left(\mathrm{M}^{++}, 100\right)$. Anal. calcd for $\mathrm{C}_{21} \mathrm{H}_{38} \mathrm{O}_{3} \mathrm{Si}: \mathrm{C}, 68.89 ; \mathrm{H}, 10.45$. Found: C, 68.76; H, 10.35 .

\section{4-(2-methoxy-3-methylphenyl)butan-1-ol (15)}

To an autoclave system equipped with a magnetic stirrer were added 14 (7.2 g, $21 \mathrm{mmol})$, dry methanol $(50 \mathrm{~mL})$ and $\mathrm{HClO}_{4}(1$ $\mathrm{mL})$. This mixture was stirred until completed homogenization and then $10 \% \mathrm{Pd} / \mathrm{C}(0.20 \mathrm{~g})$ was added. The autoclave was purged three times with hydrogen gas and then pressurized at the 4 atm. After $16 \mathrm{~h}$ at the room temperature, the excess of hydrogen gas was released. The reactional mixture was filtered through silica gel column chromatography using $\mathrm{CH}_{2} \mathrm{Cl}_{2}$. The organic phase was washed with water, brine and then dried with anhydrous $\mathrm{MgSO}_{4}$. The solvent was removed under reduced pressure and the resulting residue was purified by flash chromatography [silica gel 200-400 mesh, eluent with a mixture of 1:1 hexanes: EtOAc] to afford $\mathbf{1 5}$ (3.9 g, $20 \mathrm{mmol}, 94 \%)$ as a yellow oil. ${ }^{1} \mathrm{H}$ NMR $(300 \mathrm{MHz}) \delta$ : 1.58-1.74 (m, 1H), $2.29(\mathrm{~s}, 3 \mathrm{H}), 3.63-3.68(\mathrm{~m}, 2 \mathrm{H}), 3.65-3.70(\mathrm{~m}$, 2H), 3.73 (s, 3H), 6.92-6.97 (m, 1H), 7.01-7.03 (m, 2H); ${ }^{13} \mathrm{C} \mathrm{NMR}$

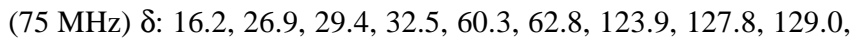
130.9, 135.1, 156.7. IR (film) $v_{\text {máx }} / \mathrm{cm}^{-1}: 3363$; LRMS (EI) $\mathrm{m} / z(\%)$ : $194\left(\mathrm{M}^{+}, 46\right), 135$ (85), 105 (100). HRMS [ESI (+)]: $m / z$ calcd for $\left[\mathrm{C}_{12} \mathrm{H}_{18} \mathrm{O}_{2}+\mathrm{Na}\right]^{+} 217.1204$, found 217.1203.

\section{4-(2-methoxy-3-methylphenyl)butanoic acid (16)}

To a two-necked flask equipped with a drying tube, magnetic stirrer and ice bath, acetone $(50 \mathrm{~mL})$ and $\mathbf{1 5}(1.4 \mathrm{~g}, 7.3 \mathrm{mmol})$ were added. The mixture was stirred until completed solubilization. The Jones reagent was slowly added until the brown color persists. After $2 \mathrm{~h}$ the reaction was quenched by addition of isopropylic alcohol and then extracted with EtOAc. The combined organic layers were washed with water, brine and then dried with anhydrous $\mathrm{MgSO}_{4}$. After the solvent removal under reduced pressure, the desired product was purified by flash chromatography [silica gel 200-400 mesh, eluent with a mixture of 1:1 hexanes: EtOAc] to afford $\mathbf{1 6}$ (1.1 g, $6.9 \mathrm{mmol}, 94 \%)$ as a yellow solid: $\mathrm{mp}: 54.9-56.0{ }^{\circ} \mathrm{C} ;{ }^{1} \mathrm{H}$ NMR (300 MHz) $\delta: 1.91-2.01(\mathrm{~m}, 2 \mathrm{H}), 2.29(\mathrm{~s}, 3 \mathrm{H}), 2.40(\mathrm{t}, J 7.4$ $\mathrm{Hz}, 2 \mathrm{H}) ; 2.69$ (t, J 7.4 Hz, 2H), 3.72 (s, 3H), 6.92-6.97 (m, 1H), 7.01-7.05 (m, 2H); ${ }^{13} \mathrm{C}$ NMR $(75 \mathrm{MHz}) \delta: 16.2,25.6,29.1,33.6$, 60.3, 124.0, 127.8, 129.4, 131.1, 156.8, 179.6; IR (film) $\mathrm{v}_{\text {máx }} / \mathrm{cm}^{-1}$ : 1706; LRMS (EI) $\mathrm{m} / z$ (\%): $208\left(\mathrm{M}^{+}, 42\right), 148$ (50), 133 (70). Anal. calcd for $\mathrm{C}_{12} \mathrm{H}_{16} \mathrm{O}_{3}: \mathrm{C}, 69.21 ; \mathrm{H}, 7.74$. Found: C, 68.76; H, 7.67.

\section{3,4-dihydro-5-methoxy-6-methylnaphthalen-1(2H)-one (9a)}

To a two-necked flask equipped with magnetic stirrer, oil bath, condenser and drying tube were added $16(2.7 \mathrm{~g}, 13 \mathrm{mmol})$ and polyphosphoric acid $(40 \mathrm{~mL})$. The mixture was stirred at $65-75^{\circ} \mathrm{C}$ for $1 \mathrm{~h}$. After that, the warm red solution was slowly poured into ice $(16 \mathrm{~g})$ and then was stirred for $20 \mathrm{~min}$. The aqueous phase was extracted with $\mathrm{Et}_{2} \mathrm{O}$. The combined organic layers were washed with water, brine and then dried with anhydrous $\mathrm{MgSO}_{4}$. After the solvent removal under reduced pressure, the desired product was purified by Kugelrohr distillation (horizontal distillation) (0.7 $\left.\mathrm{mmHg}, 175^{\circ} \mathrm{C}\right)$ to afford the tetralone $9 \mathrm{a}(2.1 \mathrm{~g}, 11 \mathrm{mmol}, 86 \%)$ as a yellow solid: mp: $57.9-58.5{ }^{\circ} \mathrm{C}$; ${ }^{1} \mathrm{H}$ NMR (300 MHz) $\delta: 2.06-2.15$ (m, 2H), $2.34(\mathrm{~s}, 3 \mathrm{H}), 2.62(\mathrm{t}, J 6.1 \mathrm{~Hz}, 2 \mathrm{H}), 2.97(\mathrm{t}, J 6.1 \mathrm{~Hz}, 2 \mathrm{H})$, $3.77(\mathrm{~s}, 3 \mathrm{H}), 7.14(\mathrm{dd}, J 8.0$ and $0.5 \mathrm{~Hz}, 1 \mathrm{H}), 7.75(\mathrm{~d}, J 8.0 \mathrm{~Hz}$, $1 \mathrm{H}) ;{ }^{13} \mathrm{C}$ NMR $(75 \mathrm{MHz}) \delta: 16.5,22.9,23.4,38.8,59.9,122.8$, 129.1, 132.3, 137.1, 137.5, 155.8, 198.0. IV (film) $v_{\text {máx }} / \mathrm{cm}^{-1}: 1682$; LRMS (EI) $m / z$ (\%): $190\left(\mathbf{M}^{+}, 100\right), 175$ (33), 134 (39); Anal. calcd for $\mathrm{C}_{12} \mathrm{H}_{14} \mathrm{O}_{2}: \mathrm{C}, 75.76 ; \mathrm{H}, 7.46$. Found: C, 75.60; H, 7.20.

\section{General procedure for reduction of the tetralones 1a-10a}

\section{Preparation of 1,2,3,4-tetrahydro-6-methoxynaphthalen-1-ol $(\mathbf{3 b})^{43}$}

To a solution of 1,2,3,4-tetrahydro-6-methoxynaphthalen-1-one (3a) $(0.36 \mathrm{~g}, 2.0 \mathrm{mmol})$ in anhydrous $\mathrm{MeOH}(6 \mathrm{~mL})$ at $0{ }^{\circ} \mathrm{C}$ and under $\mathrm{N}_{2}, \mathrm{NaBH}_{4}(0.15 \mathrm{~g}, 4.0 \mathrm{mmol}, 2$ eq. $)$ was portionwise added. The mixture was allowed to reach room temperature and then was stirred for $2 \mathrm{~h}$. The reaction mixture was quenched with water and extracted with AcOEt. The organic layer was washed with brine, dried over $\mathrm{MgSO}_{4}$ and concentrated under reduced pressure. The residue was purified by silica flash chromatography (hexanes:AcOEt, 7:3 as eluent), to give $\mathbf{3 b}$ as a colorless oil (0.32 g, $1.8 \mathrm{mmol}, 90 \%) ;{ }^{1} \mathrm{H}$ NMR $(300 \mathrm{MHz}) \delta: 1.68-2.03(\mathrm{~m}, 5 \mathrm{H})$, 2.63-2.84 (m, 2H), $3.78(\mathrm{~s}, 3 \mathrm{H}), 4.72-4.74(\mathrm{~m}, 1 \mathrm{H}), 6.61-6.62(\mathrm{~d}, J$ $3 \mathrm{~Hz}, 1 \mathrm{H}), 6.76(\mathrm{dd}, J 9 \mathrm{~Hz}$ and $J 3 \mathrm{~Hz}, 1 \mathrm{H}), 7.32(\mathrm{~d}, J 9 \mathrm{~Hz}, 1 \mathrm{H})$. The alcohol $\mathbf{3 b}$ is unstable and decomposed before fully characterization.

\section{1,2,3,4-tetrahydro-5-methoxy-6-methylnaphthalen-1-ol (9b)}

Using the general procedure described for $\mathbf{3 b}$, the $1,2,3,4$ tetrahydro-5-methoxy-6-methylnaphthalen-1-one (9a) $(0.36 \mathrm{~g}, 1.9$ mmol) was converted into 9b $(0.34 \mathrm{~g}, 1.8 \mathrm{mmol}, 95 \%) ;{ }^{1} \mathrm{H}$ NMR

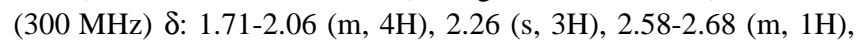
2.80-2.90 (m, 1H), $3.70(\mathrm{~s}, 3 \mathrm{H}), 4.72-4.75(\mathrm{~m}, 1 \mathrm{H}), 7.03(\mathrm{dd}, J 7.8$ and $0.6 \mathrm{~Hz}, 1 \mathrm{H}), 7.11(\mathrm{~d}, J 7.8 \mathrm{~Hz}, 1 \mathrm{H}) ;{ }^{13} \mathrm{C} \mathrm{NMR}(75 \mathrm{MHz}) \delta$ : 16.0, 18.3, 23.4, 31.9, 59.4, 68,0, 124.3, 128.8, 129.9, 130.5, 138.2, 156.0. IR (film) $v_{\text {máx }} / \mathrm{cm}^{-1}: 3237$; LRMS (EI) $\mathrm{m} / \mathrm{z}(\%): 192\left(\mathrm{M}^{++}\right.$, 
100), 177 (74), 91 (75). Anal. calcd for $\mathrm{C}_{12} \mathrm{H}_{16} \mathrm{O}_{2}: \mathrm{C}, 74.97 ; \mathrm{H}, 8.39$. Found: C, 74.68; H, 7.91.

\section{1,2,3,4-tetrahydro-4,7-dimethyl-6-methoxynaphthalen-1-ol (10b)}

Using the general procedure described for $\mathbf{3 b}$, except for the amount of $\mathrm{NaBH}_{4}$ (5 eq., $0.10 \mathrm{~g}, 2.7 \mathrm{mmol}$ ), 1,2,3,4-tetrahydro4,7-dimethyl-6-methoxynaphthalen-1-one (10a) $(0.11 \mathrm{~g}, 0.54$ mmol) was converted into $\mathbf{1 0 b}(0.10 \mathrm{~g}, 0.51 \mathrm{mmol}, 95 \%)$ as a colorless oil. The alcohol $\mathbf{1 0 b}$ is unstable and decomposed before fully characterization.

\section{Control of the bioreduction of $\alpha$-tetralones}

Tetralones 1a-10a and the corresponding tetralols 1b-10b obtained from bioreduction were compared with the racemic mixtures previously analyzed. $\mathrm{GC}$ conditions: Injector: $250{ }^{\circ} \mathrm{C}$, Detector: $350{ }^{\circ} \mathrm{C}$, Oven: $120-180^{\circ} \mathrm{C}(120 \mathrm{~min})$, Rate: $0.5^{\circ} \mathrm{C} / \mathrm{min}$, flow: $1.4 \mathrm{~mL} / \mathrm{min}$; Pressure of $\mathrm{H}_{2(\mathrm{~g})}: 10 \mathrm{psi}$, Constant pressure, Split ratio $1: 50 . t_{R}=$ retention time $(\mathrm{min})$.

\section{General procedures for biorreduction of the tetralones 1a-10a with Daucus carota root}

Conditions A: Tetralones 1a-10a (20 mg) were dissolved in a mixture of acetonitrile $(0,5 \mathrm{~mL})$ and ethanol $(0,5 \mathrm{~mL})$ and the solutions obtained were added to a suspension of freshly cut carrot root $(10 \mathrm{~g}$, thickness of $0,5 \mathrm{~cm}$, previously sterilized by washing in $2 \% \mathrm{NaOCl})$ in $40 \mathrm{~mL}$ of phosphate buffer $(0,1 \mathrm{M})$. The reaction mixtures were incubated in an orbital shaker $(180 \mathrm{rpm})$ at $32{ }^{\circ} \mathrm{C}$ for 4 days. A collected aliquot of the reactional mixture was centrifuged and the aqueous medium was extracted with EtOAc. The solvent was removed and the residual product was directly analyzed by GC. The results are summarized in Table 1 .

Conditions B: identical, except for carrot (20 g) and buffer (80 $\mathrm{mL})$.

\section{Quiral-GC data}

1a: $t_{R}=27.9$ min; $(R)-1 \mathbf{c}: t_{R}=35.09 \min \left(\right.$ minor); $(S)-\mathbf{1 c}: t_{R}=35.63$ min (major).

2a: $t_{R}=65.2 \mathrm{~min} ;(S)-\mathbf{2 b}: t_{R}=75.20 \mathrm{~min}\left(\right.$ minor); $(R)-\mathbf{2 b}: t_{R}=76.32$ min (major).

3a: $t_{R}=77.0 \mathrm{~min}$; 3b: $t_{R}=79.45 \mathrm{~min}$ (minor) and $t_{R}=80.48 \mathrm{~min}$ (major)

4a: $t_{R}=62.5 \mathrm{~min} ;(R)-\mathbf{4 c}: t_{R}=72.67 \mathrm{~min}\left(\right.$ minor); $(S)-4 \mathbf{c}: t_{R}=73.34$ min (major);

5a: $t_{R}=59.9 \min ;(R)-5 \mathbf{c}: t_{R}=66.50 \min ($ minor $) ;(S)-5 \mathbf{c}: t_{R}=67.52$ min (major);

$( \pm)-7 \mathbf{a}: 35.0$ and $35.7 \mathrm{~min}$; cis-7 $\mathbf{c}^{\prime}: t_{R}=41.88 \mathrm{~min}$ (minor) and 43.60 (major); trans-7c: $42.28 \mathrm{~min}$ (minor) and $44.32 \mathrm{~min}$ (major) 8a: $t_{R}=74.9 \mathrm{~min}$; 8c: $t_{R}=80.00 \mathrm{~min}$ (minor) and $81.03 \mathrm{~min}$ (major). 9a: $t_{R}=73.0 \mathrm{~min}$; 9b: $t_{R}=81.36 \mathrm{~min}$ (minor) and $82.35 \mathrm{~min}$ (major).

\section{ACKNOWLEDGMENT}

We are indebted to FAPESP, CAPES and CNPq, for financial support, and to Prof. Dr. L. F. Silva Jr., for fruitful discussions. We would like to thank M. V. Craveiro for the critical reading of the manuscript.

\section{REFERENCES}

1. Ghatak, A.; Dorsey, J. M.; Garner, C. M.; Pinney, K. G.; Tetrahedron Lett. 2003, 44, 4145 .

2. Yun, J.; Buchwald, S. L.; J. Org. Chem. 2000, 65, 767.

3. Armstrong, D. W.; Gahm, K. H.; Chang, L. W.; Microchem. J. 1997, 57, 149.

4. Cassady, J. M.; J. Nat. Prod. 1990, 53, 23.

5. Zhang, X.; Taketomi, T.; Yoshizumi, T.; Kumobayashi, H.; Akutagawa, S.; Mashima, K.; Takaya, H.; J. Am. Chem. Soc. 1993, 115, 3318.

6. Nishiyama, H.; Kondo, M.; Nakamura, T.; Itoh, K.; Organometallics 1991, 10,500 .

7. Faller, J. W.; Lavoie, A. R.; Organometallics 2001, 20, 5245.

8. Corey, E. J.; Helal, C. J.; Tetrahedron Lett. 1995, 36, 9153.

9. Jiang, Q.; Xiao, D.; Zhang, Z.; Cao, P.; Zhang, X.; Angew. Chem., Int. Ed. 1999, 38, 516.

10. Ohkuma, T.; Hattori, T.; Ooka, H.; Inoue, T.; Noyori, R.; Org. Lett. 2004, $6,2681$.

11. Verzijl, G. K. M.; Vries, J. G.; Broxterman, Q. B.; Tetrahedron: Asymmetry 2005, 16, 1603.

12. Yadav, J. S.; Nanda, S.; Thirupathi, R.; Rao, A. B.; J. Org. Chem. 2002, $67,3900$.

13. Jarosz, B.; Siewinski, A.; J. Basic Microbiol. 1996, 36, 245.

14. Carballeira, J. D.; Álvarez, E.; Campillo, M.; Pardo, L.; Sinisterra, J. V.; Tetrahedron: Asymmetry 2004, 15, 951.

15. Stampfer, W.; Kosjek, B.; Faber, K.; Kroutil, W.; J. Org. Chem. 2003, 68, 402.

16. Kabuto, K.; Imuta, M.; Kempner, E. S.; Ziffer, H.; J. Org. Chem. 1978, 43, 2357.

17. Abalain, C.; Buisson, D.; Azerad, R.; Tetrahedron: Asymmetry 1996, 7 , 2983.

18. Martinez, G. R.; Tetrahedron: Asymmetry 1995, 6, 1491.

19. Manito, P.; Speranza, G.; Monti, D.; Fontana, G.; Panosetti, E.; Tetrahedron 1995, 51, 11531.

20. Aina, G.; Nasini, G.; Pava, O. V.; J. Mol. Catal. B: Enzym. 2001, 11, 367.

21. Yadav, J. S.; Reddy, G. S. K. K.; Sabitha, G.; Krishna, A. D.; Prasad, A. R.; Rahaman, H. U. R.; Rao, K. V.; Rao, A. B.; Tetrahedron: Asymmetry 2007, 18, 717.

22. Ferraz, H. M. C.; Bianco, G. G.; Teixeira, C. C.; Andrade, L. H.; Porto, A. L. M.; Tetrahedron: Asymmetry 2007, 18, 1070.

23. Blanchard, N.; van de Weghe, P.; Org. Biomol. Chem. 2006, 4, 2348.

24. Baskar, B.; Ganesh, S.; Lokeswari, T. S.; Chadha, A.; J. Mol. Catal. B: Enzym. 2004, 27, 13.

25. Maczka, W.; Mironowicz, A.; Tetrahedron: Asymmetry 2002, 13, 2299.

26. Yadav, J. S.; Reddy, P. T.; Nanda, S.; Rao, A. B.; Tetrahedron: Asymmetry 2001, 12, 3381.

27. Chadha, A.; Manohar, M.; Soundararajan, T.; Lokeswari, T. S.; Tetrahedron: Asymmetry 1996, 7, 1571.

28. Cordell, G. A.; Lemos, T. L. G.; Monte, F. J. Q.; Mattos, M. C.; J. Nat. Prod. 2007, 70, 478.

29. Bruni, R.; Fantin, G.; Maietti, S.; Medici, A.; Pedrini, P.; Sacchetti, G.; Tetrahedron: Asymmetry 2006, 17, 2287.

30. Comasseto, J. V.; Omori, A. T.; Porto, A. L. M.; Andrade, L. H.; Tetrahedron Lett. 2004, 45, 473.

31. Bohlmann, F.; Zdero, C.; Le Van, N.; Phytochemistry 1979, 18, 99.

32. Ferraz, H. M. C.; Aguilar, A. M.; Silva, L. F., Jr.; Tetrahedron 2003, 59, 5817.

33. Bohlmann, F.; Zdero, C.; Phytochemistry 1977, 16, 239.

34. Ho, T.-L.; Lee, K.-Y.; Chen, C.-K.; J. Org. Chem. 1997, 62, 3365.

35. Hashmi, A. S.; Ding, L.; Bats, J. W.; Fischer, P.; Frey, W.; Chem. Eur. J. 2003, 9, 4339 .

36. Sun, N.; Chang, C.; Cassady, J. M.; Phytochemistry 1987, 26, 3051.

37. Zubaidha, P. K.; Chavan, S. P.; Racherle, U. S.; Ayyangar, N. R.; Tetrahedron 1991, 47, 5759.

38. Cannon, J. G.; Koble, D. L.; J. Med. Chem. 1980, 23, 750.

39. Naemura, K.; Fukuda, R.; Murata, M.; Konishi, M.; Hirose, K.; Tobe, Y.; Tetrahedron: Asymmetry 1995, 6, 2385.

40. Kasai, M.; Kawai, K.; Imuta, M.; Ziffer, H.; J. Org. Chem. 1984, 49, 675.

41. Prelog, V.; Pure Appl. Chem. 1964, 9, 119.

42. Bégué, J.; Cerceau, C.; Dogbeavou, A.; Mathé, L.; Sicsic, S.; J. Chem. Soc., Perkin Trans 1 1992, 3141.

43. Bagal, S. K.; Adlington, R. M.; Baldwin, J. E.; Marquez, R.; Cowley, A.; Org. Lett. 2003, 5, 3049. 